\title{
Research on correlation of commercial circulation service industry model and higher vocational education
}

\author{
Jiaqiong Kang ${ }^{1}$, Guangqi $\mathrm{Li}^{1}$ \\ ${ }^{1}$ Chongqing Business Vocational College, Chongqing, 400036, China
}

Keywords: Commercial circulation service industry; higher vocational education

\begin{abstract}
Commercial circulation service industry is the leading industry of national economy and an important symbol of economic development level, and its development is of important strategic significance in driving the local economic development, guiding the consumption, increasing the employment rate and promoting the strategic adjustment of economic structure and transformation of economic growth pattern. With the constant deepening of economic system reform in China, the scale and strength of traditional state-owned commercial circulation enterprises have increased rapidly. Based on the analysis of the features and model of commercial circulation service industry, in this paper, the correlation of the current situation of human resources of commercial circulation service industry and higher vocational education is studied and the idea and method of improving the level of commercial talents by higher vocational education are put forward.
\end{abstract}

\section{Introduction}

As a middle bridge of production and consumption, commercial circulation industry plays an important role in national economy development, becomes an important cornerstone that lays the dominant position of China's national economy and constantly creates commercial miracles. However, from the development of modern science and technology and the development level of commercial circulation service industry, the commercial circulation service industry has such problems as slow circulation velocity, low efficiency and high cost. It can not only promote the development of commercial circulation industry, but also drives the development of economy by breaking the constraints of these bottlenecks. The sluggish development of commercial circulation service industry has three reasons: first, the professional and practical talents are lacked; second, the talents mainly concentrate in the traditional service industry; third, the employees of commercial circulation industry are of low professional level and quality. Therefore, to change the shortcomings of commercial circulation service industry, it must vigorously develop and introduce high-quality talents. The higher vocational colleges are the output base of professional technicians, the concept of modern higher vocational education should be "employment-oriented and vocational ability cultivation-centered", and its goal is to cultivate "high-quality and skilled-oriented" professional talents. How to innovate the high vocational talents cultivation model to cultivate multi-level and innovative commercial talents is the future development trend of high vocational colleges and also development direction of commercial circulation service industry in the future.

\section{Features of commercial circulation service industry}

Commercial circulation industry, also called commercial circulation service industry, refers to the industry that engages in commodity and service transaction activity in the national economy, specifically including wholesale, retail, logistics and catering industry specialized in commodity (service) and buying and selling activity in industry and agriculture. From this definition, the commercial circulation industry includes traditional commerce, modern logistics industry, partial business service industry and partial productive service industry. The commercial circulation service industry is a service industry that occurs with the development of information technology and knowledge economy, transforms the traditional service industry with modern new technology, new formats and new service mode, creates demand, guides consumption, and provides high value-added, high-level and knowledge-based production and life services to the society. The main 
features of commercial circulation service industry are as follows:

\section{Continuously increased GDP proportion}

At present, the output and employment of service industry in developed countries account for about $70 \%$ of GDP; however, that in some developed countries or cities, such as Singapore, Hong Kong, Tokyo, New York and London, account for about $80 \%$ of GDP and the modern producer or productive service industry accounts for $70 \%$ of the service industry, indicating that $50 \%$ of the social wealth comes from the creation of service industry in the modern society and the creation of modern social wealth has relied on or completely relied on the social soft power and service. With the further development of market economy and continuous increase of people's consumption level, the agriculture and industry-oriented social model has gradually changed into service industry-dominated one and the social models of some western developed countries have completed the transformation into service-industry-dominated model. In US, the current agricultural employment accounts for about $1 \%$ of its total population and the industrial employment accounts for about $14 \%$ of the total population; however, the employment of service industry accounts for up to $80 \%$, indicating that an era of all-people service industry has come quietly.

\section{Intensive knowledge elements}

The commercial circulation service industry is a knowledge intensive industry and its implementation rule has gradually changed from physical power in early stage to capital, knowledge and technology to finally realize the education as the main body, which shows the social evolution process is actually the process of the continuous evolution and deepening of production elements. The foreign scholars think the modern service industry is to introduce the knowledge, technology and human into the main channel of material production. Therefore, the modern commercial circulation service industry is the knowledge intensive industry integrating high level, high education and high experience and the knowledge and education level of its employees are generally higher than that of manufacturing industry.

\section{"Three news" and "three highs"}

In the commercial circulation service industry, "three news" refers to new technology, new formats and new method and "three highs" refers to high human capital content, high technical content and high value added. The modern service industry must integrate the comprehensive function of modern city and satisfy the development needs of modern people and city with a new format. To develop the modern service industry, it should be noted that the tower base of the human resources of modern service industry is the labors with systematic training and learning and advanced service concept and consciousness.

\section{Commercial circulation service industry model}

The acceleration of the development of commercial circulation service industry in China can plays an important role in connecting production and demand, guiding consumption, promoting production, increasing employment and stimulating economic growth. However, the commercial circulation service industry in China still has some problems that cannot be ignored now and some problems that restrict the development of commercial circulation service industry and consumer market seriously hinder the development of commercial circulation service industry. Recently, although the scale of traditional state-owned commercial circulation enterprises has been expanded rapidly and their and competitive power has been improved obviously, the traditional business service model of wholesale agency is still implemented in the long-term development. With the change of market environment and development of Internet as well as great change of the transaction mode of commercial circulation industry, the limitations of the traditional wholesale agency model of traditional state-owned commercial circulation enterprises become more and more prominent, mainly manifested in the short value chain, small development space and great operation risk, thus restricting the sustainable development of traditional state-owned commercial circulation enterprises to a great extend. Under the new situation that the global economic integration accelerates, the commercial circulation enterprises can only continuously strengthen their core competitiveness only by taking a path of innovative business model in order to find the new 
development opportunity in the fierce market competition.

\section{Correlation of current situation of human resources of commercial circulation service industry and higher vocational education}

\section{Employees still concentrate in the traditional service industry}

At present, the employees of service industry in China are still distributed in three traditional service industries: wholesale and retail, transportation and storage, and post industry. As the information transmission, computer software, financial industry, education and science and technology service department with high knowledge content have high requirements on the knowledge level and personal quality of employees, so the number of employees is far below the total employment of service industry.

Employees are of different quality and ability

Due to the different career choice, the employees of service industry are greatly different in knowledge level, education level and personal equality. The employees in transportation, storage, wholesale and retail, catering industry and other service department generally have high school degree or below, with low personal quality; those in education and cultural department generally have college degree and above; those in financial industry, information transmission and computer software industry generally have bachelor degree and above.

\section{Correlation of level of employees and higher vocational education}

It can be seen from the above that the education level and personal quality of employees of commercial circulation service industry cannot satisfy the requirements of modern enterprises, so new requirements and challenges are put forward on the talents cultivation, degree education and knowledge level of high vocational colleges. The society and commercial circulation service industry's demand for various degree, knowledge and skilled talents is inseparable with the cultivation and shaping of human resources of higher vocational colleges and also has direct and important relations with the running level, teaching ability, education degree and professional skill training level of higher vocational colleges. Therefore, to improve the quality and cultural level of employees of commercial circulation service industry and strengthen the comprehensive strength and international competitiveness of commercial circulation industry, it must cultivate a lot of intelligent practical commercial talents that adapt to the development requirements of modern commercial circulation service industry, and define and adjust the talents cultivation and education plan of higher vocational colleges to improve the comprehensive quality of commercial circulation team, so as to provide powerful talents supports for the development of modern commercial circulation service industry.

\section{Idea and method of improving the cultivation of commercial talents of higher vocational education}

\section{The major setup should integrate with the market demand}

The major setup is an important embodiment that the educational program of higher vocational colleges adapts to the market demand and also a specific embodiment that the higher vocational colleges provide excellent professional talents to the economic development. The education must adapt to the social and market demands to ensure the talents of colleges make corresponding contribution to the social and economic development. Whether the talents are required by the society will impose influences on the market labor structure, industrial structure and technological structure.

\section{Reform the teaching link of theory courses}

The theory courses of higher vocational colleges mainly include cultural basic courses, professional basic courses and professional courses. The cultural basic courses are the basis for all disciplines, the professional basic courses serve the professional courses and practical courses and also lay a foundation for professional courses, and the professional courses are the professional ability, knowledge and technical level required by students when they enter the society. In the 
reform of theory courses, the students should be allowed to freely choose the professional courses according to the cultivation target and task of major to enhance their learning initiative and improve their professional quality, knowledge and skills.

\section{Strengthen the teaching of practical link}

The practical teaching of graduates of higher vocational colleges is an effective teaching mode to improve and exercise students' ability of practice and thought and strengthen the combination of theory and practice and plays an important role in cultivating intelligent application and skilled talents. The practical teaching cannot only enhance students' love to their major to make them master the theoretical knowledge skillfully, but also is of positive realistic significance in cultivating students' fine quality and good professional ethnics. It is required to ensure the course learning of practical link and the class hour, create good practical teaching environment, strengthen the management and guidance of students and further improve their quality at all aspects.

\section{Establish on-campus and off-campus training base}

The training base is an carrier of practical teaching and an important link that strengthens the combination of theory and practice, and used for the graduation practice of professional courses and graduation practice of students. The training base of higher vocational colleges should satisfy the requirements of teaching and production practice. Recently, with the rapid development of commercial circulation service industry as well as modern logistics, automobile, e-commerce, finance and accounting, computer and other industry, the training of higher vocational colleges must integrate with the realistic development and it is required to establish the training rooms and bases with various scales and projects to exercise and improve students' practical operation ability. The higher vocational education should deeply carry out various practical teaching, further strengthen students' direct knowledge and mastery of operating skills by field teaching, teaching practice, course practice and graduation practice, and promote the development of students' observation ability, attention, ability of thinking and other psychological traits to form good qualities, such as carefulness, patience and sureness. The teaching practice should enable students to master certain basic operating skill in this major, smoothly complete the work task as required and cultivate students' good good qualities, such as professional emotion, will, ethnics and mutual respect and cooperation, thus making them prepare to enter the society in terms of thought, knowledge and skills.

\section{Conclusion}

In conclusion, facing the increasingly fierce market competition, the product competition model of traditional state-owned commercial circulation enterprises with price as the main carrier cannot be accepted by the market. The modern market competition is all-around competition in terms of product, service, channel and brand. However, from the current situation of commercial circulation services at present, the phenomena, such as lacking of intelligent talents, low knowledge content of employees, lacking of professional talents by intensive enterprises, have become indisputable facts. With the bigger and bigger gap between commercial service in China and international level, it is required to improve the commercial service level, enhance the enterprise competitiveness and strengthen the talents cultivation and construction. Therefore, the higher vocation education that cultivates professional talents for commercial circulation service industry should abandon the traditional model in major setup and talents cultivation, accelerate the integration with market and continuously provide high-quality professional talents to enterprises in order to make important efforts to drive the development of commercial circulation service industry and its influence at home and abroad, seize the new strategic opportunity, actively participate in international competition and promote the new pattern of world service transaction equivalent to the position of China as a great power.

\section{Acknowledgments}

This paper is a part of 2013 Chongqing Social Science Planning Youth Project, "Research on 
Development Model of Commercial Circulation Service Industry by Higher Vocational Education in Chongqing” (No.: 2013QNJY33)

\section{References}

[1] Wang Lingfang. Analysis on Industrial Relationship and Spread Effect of Commercial Circulation Industry in Zhejiang Province. Zhejiang Gongshang University, 2012:1-87.

[2] Song Ze. Thirty Years of Reform and Opening Up: Retrospect and Prospect of Commercial Circulation Service Industry. Journal of Guangdong University of Business Studies, 2008(5):39-44.

[3] On Reform and Practice of Commercial Professional Talents Cultivation Model from Higher Vocational Colleges Based on Working Process. www.hbrc.com, August 23, 2013 11:21.

[4] Lan Ling. Research on Development of Higher Vocational Education and Linkage Countermeasures to Talents Demand of Modern Service Industry in Guangdong Province. Work \& Study Abroad (Employment), 2011(13):57-59.

[5] Lan Ling. Research on Development of Higher Vocational Education and Linkage Countermeasures to Talents Demand of Modern Service Industry in Guangdong Province. Work \& Study Abroad (Employment), 2011(13):57-59.

[6] Huang Rihua. Accelerating the Development of Modern Commercial Circulation Service Industry. www.cnhubei.com-Hubei Daily. May 5, 2009.

[7] Wang Li. Innovation Research of Business Model of Traditional State-Owned Commercial Circulation Enterprises-From the Perspective of Supply Chain Management. Modern Business Trade Industry. 2011, 23(7): 1-2.

[8] Xu Yong'an. On How to Promote the Modern Commercial Circulation Talents Construction in Zhejiang Province. Commercial Times, 2007(16): 20-23.

[9] Wang Li. Innovation Research of Business Model of Traditional State-Owned Commercial Circulation Enterprises-From the Perspective of Supply Chain Management. Modern Business Trade Industry. 2011, 23(7): 1-2. 